BEZPIECZEŃSTWO

\author{
LUKASZ JUREŃCZYK
}

Uniwersytet Kazimierza Wielkiego

ORCID: 0000-0003-1149-925X

\section{Polityka bezpieczeństwa i obrony Australii w drugiej dekadzie XXI wieku wobec wzrostu potęgi Chin}

\author{
Australia's security and defence policy in the 2010s \\ in the context of the rise of China
}

The subject of the article is the security and defence policy of Australia in the 2010s in view of the rapidly growing power of the People's Republic of China. The article analyses issues such as the potential, values, interests and threats of Australia; strategic dimension of Australia's security and defence policy; Australia's cooperation with the United States in the context of the rise of China; and Australia's attitude towards China's assertive actions in the AsiaPacific. The aim of the article is to analyse and evaluate Australia's security and defence policy towards the growing power of China. The main research problem is included in the question of whether Australia adequately and sufficiently responds to the increasing military potential of the Middle Kingdom. The thesis of the article assumes that while the directions of Australian policy are justified, its scale is insufficient. The most important elements in securing interests in the context of China's growing power is increasing its own defence capabilities and deepening multi-faceted cooperation with allies and partners of the Pacific region. This must be accompanied by caring for the correctness of relations with China and efforts to reduce tensions between the People's Republic of China and the United States. The article is based on the theory of structural realism of the defensive type. The article uses the method of source text analysis.

Keywords: Australia, China, United States, security policy, defence policy

Słowa kluczowe: Australia, Chiny, Stany Zjednoczone, polityka bezpieczeństwa, polityka obrony 


\section{Wprowadzenie}

Prowadzona obecnie w Australii debata naukowa i publiczna na temat polityki bezpieczeństwa i obrony koncentruje się na wynikającej ze wzrostu potęgi Chin zmianie układu sił w regionie Azji i Pacyfiku oraz na świecie. Celem niniejszego artykułu jest analiza i ocena kierunków polityki bezpieczeństwa i obronności Australii w kontekście szybko rosnącego potencjału militarnego Państwa Środka. Główny problem badawczy zawiera się w pytaniu, czy Australia w odpowiedni sposób i w wystarczającym stopniu reaguje na rozwój armii i wzmożoną aktywność wojskową Chińskiej Republiki Ludowej. Aby odpowiedzieć na pytanie główne, należy najpierw ustalić, czy wzrost potęgi Chin stanowi zagrożenie dla bezpieczeństwa Australii i jej obywateli. Główną hipotezą badawczą jest założenie, że kierunki działania Canberry wobec wzrostu potęgi Pekinu są adekwatne, ale ich skala jest niewystarczająca. Wzmacnianie własnego potencjału wojskowego oraz intensyfikacja współpracy polityczno-wojskowej z sojusznikami i partnerami, przede wszystkim Stanami Zjednoczonymi, jest dobrym kierunkiem działania. Towarzyszące temu zabiegi na rzecz utrzymania poprawnych stosunków z Chinami i próby łagodzenia napięć między ChRL i USA sprzyjają realizowaniu przez Australię strategicznych celów i interesów. Rząd w Canberze powinien jednak w większym stopniu skupić się na współpracy z innymi niż Pekin partnerami z Azji (głównie gospodarczej) i dalej rozwijać relacje z państwami Oceanii. Powyższe działania są niezbędne, ponieważ szybki wzrost potęgi i asertywności Chin może zagrozić bezpieczeństwu Australii i jej mieszkańców. Potwierdza to fakt, że ChRL coraz częściej demonstruje siłę militarną w stosunkach z sąsiadami, próbując w ten sposób osiągnąć swoje cele polityczne.

Polityka bezpieczeństwa i obrony Australii wpisuje się w defensywny typ teorii realizmu strukturalnego. Według Kennetha Waltza anarchiczny ład w środowisku międzynarodowym rzutuje na motywy, którymi państwa kierują się w polityce zagranicznej, i kształtuje ich działania zewnętrzne. Głównym celem w takim systemie jest przetrwanie ${ }^{1}$, a zasadniczy sposób jego realizacji to stworzenie i utrzymanie systemu równowagi sił ${ }^{2}$ Stephen Walt twierdzi, że w celu zapewnienia sobie bezpieczeństwa państwa dążą przede wszystkim do zbalansowania głównego niebezpieczeństwa. Chodzi więc nie tyle o zrównoważenie siły tego podmiotu, co o neutralizowanie stwarzanego przez niego

1 K.N. Waltz, Theory of international politics, Random House, New York 1979, s. 91-92.

2 J. Czaputowicz, Bezpieczeństwo międzynarodowe. Współczesne koncepcje, Wydawnictwo Naukowe PWN, Warszawa 2012, s. 113. 
zagrożenia. Jednym z głównych założeń realizmu strukturalnego typu defensywnego jest prymat maksymalizacji własnego bezpieczeństwa nad maksymalizacją siły relatywnej3 ${ }^{3}$ W typowej sytuacji państwa tworzą sojusze, najczęściej z innymi państwami, które czują się zagrożone działaniami podmiotu trzeciego. Zabiegając o uzyskanie i utrzymanie stanu równowagi siły, państwa powinny koncentrować się na rozwoju potencjału defensywnego i unikać podejmowania ryzykownych działań ${ }^{4}$. Ubocznym i najczęściej niezamierzonym rezultatem zwiększania poziomu własnego bezpieczeństwa może być spadek poczucia bezpieczeństwa u innych podmiotów. Ten swoisty dylemat bezpieczeństwa można jednak złagodzić poprzez podejmowanie działań kooperatywnych ${ }^{5}$. Podczas pisania niniejszego artykułu wykorzystana została metoda analizy źródeł tekstowych.

\section{Potencjal, wartości i interesy Australii oraz zagrożenia dla kraju}

Australia z prawie $7,69 \mathrm{mln} \mathrm{km}^{2}$ powierzchni jest szóstym pod względem wielkości państwem na świecie. Jako jedyna leży na wyspie-kontynencie, której wielkość daje dużą głębię strategiczną. Długa linia brzegowa i oddalenie od innych lądów zapewnia szeroki pas jurysdykcji morskiej i naturalną barierę przed potencjalnymi agresorami. Australię zamieszkuje zaledwie $25,1 \mathrm{mln}$ ludności, co plasuje ją pod tym względem dopiero na 56 miejscu na świecie. Choć więc jej terytorium jest tylko nieco mniejsze od Chin, które zajmują 9,56 mln km² to na korzyść Państwa Środka zdecydowanie przemawia czynnik demograficzny, żyje tam bowiem 1,397 mld ludzi.

Korzenie większości Australijczyków sięgają Europy, ale jej społeczeństwo ma charakter wielokulturowy i wieloetniczny, a prawie 2 proc. mieszkańców stanowią Chińczycy. Jak dotąd zróżnicowanie etniczne państwa nie pociągało za sobą poważniejszych konfliktów społecznych, pomijając kwestię Aborygenów. Dominującą religią jest chrześcijaństwo, natomiast każdą z pozostałych wyznaje nie więcej niż 3 proc. populacji, a ich praktykowanie nie natrafia na ograniczenia ze strony państwa. Australia jest demokratycznym państwem prawa przestrzegającym wysokich standardów pluralizmu politycznego

3 S.M. Walt, The origins of alliances, Cornell University Press, Ithaca-New York 1987, s. $262-286$.

4 P. Kmiecik, Realizm strukturalny ofensywny, defensywny i zależny, „Nowa Strategia” [online], 26 XI 2016 [dostęp: 17 X 2019], dostępny w internecie: <http://www.nowastrategia.org.pl/realizm/>.

5 S.M. Walt, The origins..., s. 262-286. 
i praw człowieka. Ma rozwiniętą gospodarkę kapitalistyczną z PKB na poziomie 1,5 bln dol. w 2018 r. i bardzo wysokim PKB per capita, sięgającym 59,7 tys. dol. ChRL ma ustrój socjalistyczny z omnipotencją Komunistycznej Partii Chin (KPCh), która nagminnie łamie prawa człowieka i nie respektuje zwyczajów oraz wierzeń grup mniejszościowych. System gospodarczy Chin jest hybrydą między kapitalizmem i socjalizmem. O ile jednak Państwo Środka ma drugą po Stanach Zjednoczonych gospodarkę na świecie (PKB na poziomie 14,1 bln dol. w 2018 r.), to chińskie społeczeństwo jest znacznie uboższe niż australijskie, ponieważ PKB per capita wynosi tam zaledwie 10,1 tys. dol. ${ }^{6}$ W XXI w. procentowy wzrost PKB Chin był jednak ponad trzykrotnie wyższy niż w przypadku Australii. Jeśli tendencje rozwojowe utrzymają się, to różnica w wielkości gospodarek szybko będzie rosnąć na korzyść Chin, a poziom zamożności obywateli obu państw będzie się sukcesywnie wyrównywał. Australia ma dostęp do szerokiej gamy zasobów naturalnych, w tym metali i surowców energetycznych. Szybko rozwijającym się Chinom bardzo ich potrzeba, a same dysponują relatywnie ubogimi złożami. Australia określana jest jako aktywne dyplomatycznie średnie mocarstwo poważnie zaangażowane w regionie Azji i Pacyfiku, w tym na kontynencie azjatyckim ${ }^{7}$. Chiny z kolei możemy nazwać wielkim mocarstwem, którego główne interesy zlokalizowane są w Azji, ale wykraczają też poza kontynent i sięgają całego globu.

Wśród podstawowych interesów Australii w drugiej dekadzie XXI w. znajdowały się:

- utrzymanie niepodległości i wolności od zewnętrznych interwencji i nacisków;

- zachowanie demokratycznego systemu politycznego i wartości demokratycznych;

- ochrona ludności, terytorium i jego zasobów;

- zachowanie stabilnego, pokojowego i opartego na poszanowaniu prawa porządku międzynarodowego;

6 Report for selected countries and subjects, „International Monetary Fund” [online], April 2018, [dostęp: 5 II 2019], dostępny w internecie: $<$ https://www.imf.org/external/pubs/ft/ weo/2018/01/weodata/weorept.aspx?pr. $x=61 \& p r . y=5 \&$ sy $=2016 \&$ ey $=2023 \& s c s m=1 \& s s$ $\mathrm{d}=1 \&$ sort $=$ country $\& \mathrm{ds}=. \& \mathrm{br}=1 \& \mathrm{c}=193 \& \mathrm{~s}=\mathrm{NGDPD}$, PPPGDP,NGDPDPC,PPPPC,LP \& grp $=0 \& a=>$.

7 R. Medcalf, Canberra's Beijing balance: Australian perceptions of and responses to Chinese power, [w:] China's power and Asian security, ed. M. Li, K.M. Kemburi, Routledge, London-New York 2015, s. 164-165.

8 Tenże, Grand stakes: Australia's future between China and India, [w:] Asia responds to its rising powers: China and India, ed. A.J. Tellis, T. Tanner, J. Keogh, National Bureau of Asian Research, Seattle 2011, s. 197-200. 
- utrzymanie zrównoważonego rozwoju, konkurencyjności i współpracy gospodarczej z partnerami.

Główne zagrożenia, z którymi Australia musiała się zmierzyć w drugiej dekadzie XXI w., obejmowały':

- szpiegostwo i ingerencje zewnętrzne;

- niestabilność państw rozwijających się;

- nieprzyjazną aktywność w cyberprzestrzeni;

- rozprzestrzenianie broni masowego rażenia;

- przestępczość zorganizowaną;

- konflikty międzypaństwowe lub wymuszenia ze strony mocarstw poważnie wpływające na interesy Australii;

- terroryzm i ekstremizm międzynarodowy.

Należy zauważyć, że kilka głównych zagrożeń dla Australii jest konsekwencją m.in. polityki ChRL i aktywności podmiotów działających na jej terytorium. Dotyczy to przede wszystkim szpiegostwa i zewnętrznych ingerencji, wrogich działań w cyberprzestrzeni oraz wymuszeń i konfliktów między państwami. Chiny rywalizują w regionie Azji i Pacyfiku ze Stanami Zjednoczonymi, ale mają też poważne spory terytorialne z sąsiadami. Rosnące w siłę Państwo Środka prowadzi coraz bardziej asertywną politykę międzynarodową i próbuje oddziaływać na swoich partnerów, demonstrując siłę wojskową i sięgając po nielegalne metody.

\section{Strategiczny wymiar polityki bezpieczeństwa i obronności Australii}

Mimo korzystnego położenia geograficznego Australia odczuwała w XX w. potencjalne zagrożenie ze strony mocarstw azjatyckich: w pierwszej połowie stulecia głównie Japonii, a w drugiej - Związku Radzieckiego. Imperia te miały znaczne aspiracje terytorialne i gdyby nie zostały powstrzymane przez Stany Zjednoczone, mogłyby sięgnąć wyspy-kontynentu. Współcześnie mocarstwem azjatyckim, które szybko rozszerza swoje wpływy w regionie, jest ChRL. Jak dotąd jej ekspansja tylko w ograniczonym wymiarze ma charakter terytorialny, jednak w kontekście sporów, które prowadzi na tym tle z sąsiadami, jej wzrost asertywności i tak budzi poważne obawy w regionie, w tym w Australii. Stany Zjednoczone wprowadzają wobec Chin elementy

9 Strong and secure. A strategy for Australia's national security, Australian Government Department of the Prime Minister and Cabinet, Canberra 2013, s. 10-11, dostępny w internecie [dostęp: 10 II 2019]: <https://www.files.ethz.ch/isn/167267/Australia\%20A\%20 Strategy $\% 20$ for $\% 20$ National $\% 20$ Securit.pdf $>$. 
polityki powstrzymywania, próbując $\mathrm{w}$ ten sposób ograniczyć wzrost potęgi azjatyckiego mocarstwa. Przez dekady Australia opierała swoje bezpieczeństwo zewnętrzne na sojuszniczej współpracy z USA, a jego praktycznym gwarantem była stała obecność amerykańskich sił w regionie Azji i Pacyfiku. Ponieważ Stany Zjednoczone mają status globalnego supermocarstwa, zasadniczo zależy im na utrzymaniu obecnej struktury systemu światowego. Chiny z kolei, jako mocarstwo wschodzące, dążą do ewolucji tego systemu w kierunku wielobiegunowym, m.in. poprzez próbę równoważenia amerykańskich wpływów.

W XXI w. komunistyczne Chiny próbują kreować swój wizerunek jako państwa, któremu zależy na pokoju i bezpieczeństwie. W retoryce stosowanej na forum międzynarodowym akcentują te pozytywne wartości, promując wielowymiarową współpracę między państwami, a w działaniach wobec innych uczestników stosunków międzynarodowych skupiają się przede wszystkim na instrumentach z zakresu soft power. Prezentowana przez Pekin koncepcja harmonijnego świata była dobrze przyjmowana przez wielu wysokich rangą polityków z całego świata już w okresie prezydentury Hu Jintao (III 2003 III 2013). Bardzo pozytywnie odnosił się do niej m.in. Kevin Rudd, dwukrotny premier (XII 2007 - VI 2010, VI 2013 - IX 2013) i minister spraw zagranicznych Australii (IX 2010 - II 2012), wywodzący się z Australijskiej Partii Pracy. Osobista sympatia tego polityka do Państwa Środka wynikała m.in. z tego, że przez lata wykładał historię Chin. Komunikację z chińskimi elitami politycznymi ułatwiała mu dobra znajomość języka mandaryńskiego, a zacieśnianie współpracy z państwami azjatyckimi, w tym z Chinami, było jednym z głównych celów jego polityki zagranicznej.

Kevin Rudd miał duże aspiracje w zakresie kształtowania regionalnego środowiska bezpieczeństwa. W 2008 r. zaproponował koncepcję Wspólnoty Azji i Pacyfiku (Asia Pacific Community), zakładającą stworzenie systemu wzorowanego w pewnym stopniu na koncercie mocarstw (concert of powers), ale istotnie modyfikującą jego klasyczne rozumienie. Projekt Kevina Rudda przyjmował bowiem, że najpotężniejsze mocarstwa, tj. USA i ChRL, miały się dzielić siłą z mocarstwami regionalnymi i lokalnymi. Koncepcja ta została jednak odrzucona przez chińskie kierownictwo, które widziało w niej narzędzie zawoalowanego powstrzymywania rozwoju własnej potęgi ${ }^{10}$.

10 T.S. Seng, Engaging China and the United States: perils and prospects for ASEAN diplomacy in the age of rebalancing, [w:] New dynamics in US-China relations contending for the Asia-Pacific, ed. L. Mingjiang, K. M. Kemburi, Routledge, London-New York 2015, s. 71, 77. 
Konieczność zacieśniania współpracy z dynamicznie rozwijającą się Azją, w tym z Chinami, dostrzegała również wywodząca się z tego samego ugrupowania politycznego następczyni Rudda, premier Julia Gillard (VI 2010 - VI 2013). Zaproponowała na przykład, by studenci obowiązkowo uczyli się jednego z głównych języków azjatyckich, mając do wyboru m.in. mandaryński. 5 kwietnia 2013 r. premier Gillard i prezydent Xi Jinping (od III 2013) podpisali w Pekinie porozumienie o strategicznym partnerstwie między Australią i Chinami, zgodnie z którym co roku odbywają się dwustronne spotkania na poziomie głów państw, szefów rządów i ministrów. Jednym z głównych elementów strategicznego partnerstwa jest dialog w zakresie polityki zagranicznej i bezpieczeństwa, w którym udział biorą ministrowie spraw zagranicznych i obrony ${ }^{11}$.

Rozwojowi wieloaspektowej współpracy z Chinami wiele uwagi poświęcali też premierzy wywodzący się z Liberalnej Partii Australii: Tony Abbot (IX 2013 - IX 2015), Malcolm Turnbull (IX 2015 - VIII 2018) i Scott Morrison (od VIII 2018). Czynili to jednak, czując coraz większy niepokój wobec szybko rosnącego w siłę Państwa Środka, które stawało się coraz bardziej asertywnym graczem na arenie międzynarodowej. 17 listopada 2014 r. prezydent Xi wygłosił w parlamencie Australii przemówienie, w którym potwierdził przywiązanie Chin do pokoju i harmonijnego rozwoju, ale także gotowość obrony własnych interesów. Powiedział również, że jego kraj chce pogłębiać strategiczne partnerstwo z Australią ${ }^{12}$. Tego samego dnia podpisane zostało porozumienie o wolnym handlu między oboma państwami. W okresie sprawowania urzędu premiera przez Malcolma Turnbulla między Pekinem a Canberrą doszło do licznych tarć dyplomatycznych, co wyraźnie ochłodziło wzajemne relacje polityczne. Po przejęciu urzędu przez Scotta Morrisona nastąpiła próba ich naprawy, co w listopadzie 2018 r. docenił premier Li Keqiang, stwierdzając, że stosunki chińsko-australijskie są „w punkcie zwrotnym po okresie wzlotów i upadków"13. Na drodze ku normalizacji stanęly jednak pewne różnice zdań,

11 R. Mishra, Australia-China strategic partnership, Institute for Defence Studies and Analyses, [New Delhi] 13 V 2013, s. 3, dostępny w internecie [dostęp: 20 II 2019]: <https:// www.files.ethz.ch/isn/164925/IB_Australia-China_RMishra130513.pdf>.

12 Full text of Chinese president Xi Jinping's address to Australia's Parliament, ,The Straits Times" [online], 19 XI 2014, [dostęp: 17 X 2019], dostępny w internecie: <https://www. straitstimes.com/asia/australianz/full-text-of-chinese-president-xi-jinpings-addressto-australias-parliament>.

13 A. Hodge, ASEAN summit: Chinese premier Li Keqiang says Australia's relationship with Beijing is at a turning point, ,The Australian” [online], 14 XI 2018, [dostęp: 17 X 2019], dostępny w internecie: <https://www.theaustralian.com.au/nation/politics/asean-summitchinese-premier-li-keqiang-says-australias-relationship-with-beijing-is-at-a-turning-point/ news-story/7b3fe77630438e9acd33ae2a8d213ce4>. 
m.in. w kwestiach gospodarczych. W sierpniu 2019 r. wbrew stanowisku Pekinu premier Morrison uznał Chiny za państwo rozwinięte gospodarczo i wezwał jego władze do większej transparentności w relacjach handlowych oraz przyjęcia współodpowiedzialności za zmiany klimatyczne ${ }^{14}$.

W obliczu wzrostu potęgi Chin i zmiany sytuacji strategicznej w regionie Azji i Pacyfiku Australia tworzy w ostatnich latach podstawy nowej strategii wobec Państwa Środka. Według Roya Medcalfa obejmuje ona dwa podstawowe elementy - zaangażowanie i zabezpieczanie (engagement and hedging). Pierwszy polega na rozwijaniu z Chinami oraz innymi państwami regionu współpracy na rzecz utrzymania tam pokoju, bezpieczeństwa i stabilności. Na drugi składa się kilka kwestii szczegółowych, w tym wewnętrzne balansowanie (internal balancing) poprzez modernizację własnego potencjału militarnego i zewnętrzne balansowanie (external balancing) skupiające się głównie na zacieśnianiu sojuszniczej współpracy ze Stanami Zjednoczonymi ${ }^{15}$. Gdyby wymagała tego zmiana okoliczności międzynarodowych, preferowana obecnie strategia zabezpieczania może ewoluować w kierunku strategii powstrzymywania (containment). Obecnie blisko współpracujące z USA państwa regionu, w tym Australia, są jeszcze w stanie samodzielnie zabezpieczać swoje podstawowe interesy i z tego względu nie muszą pilnie budować z Waszyngtonem wymierzonego przeciwko Pekinowi wielostronnego sojuszu polityczno-wojskowego. Realizowana przez Amerykanów polityka blokowania rozwoju potęgi i wpływów Chin na obszarze Azji i Pacyfiku wpływa jednak negatywnie na relacje między mocarstwami, przez co pogłębia się dylemat bezpieczeństwa $\mathrm{w}$ tym regionie ${ }^{16}$. Jeżeli napięcia między Waszyngtonem i Pekinem będą rosnąć, państwa regionu mogą zostać zmuszone do bardziej jednoznacznego opowiedzenia się po stronie jednego z mocarstw w kontrze do drugiego.

Wzrost potęgi Chin i nasilenie się rywalizacji między mocarstwami w regionie Azji i Pacyfiku zmotywowały władze Australii do wydania na początku 2013 r. pierwszej w historii strategii bezpieczeństwa narodowego (SBN) pt. 'Silna i bezpieczna'. Dokument stwierdza, że największy wpływ

14 Australian PM Scott Morrison warns global trade rules must be reshaped to account for China's rapid growth, ,South China Morning Post” [online], 24 IX 2019, [dostęp: 17 X 2019], dostępny w internecie: <https://www.scmp.com/news/china/article/3030046/ australian-pm-scott-morrison-says-china-must-step-climate-change-newly $>$.

15 R. Medcalf, Canberra's Beijing balance..., s. 163-164.

16 R.W. Hu, Strategic trust deficit and its impact on the future of China-US relations, [w:] New dynamics..., s. 52. 
na kształtowanie regionalnego środowiska strategicznego będą miały relacje między Chinami i Stanami Zjednoczonymi. Zaakcentowano w nim, że USA, będące najbliższym sojusznikiem Australii i największą potęgą militarną na świecie, zwróciły się ku regionowi Azji i Pacyfiku, a Chiny - jej główny partner handlowy - zaczynają być coraz bardziej aktywne w regionie i budują znaczący potencjał militarny. W strategii wyrażono nadzieję, że Waszyngton i Pekin we współpracy z Canberrą i innymi partnerami będą się skupiać na zachowaniu stabilności i bezpieczeństwa w regionie ${ }^{17}$.

Wydanie SBN nie zmieniło tradycji cyklicznego publikowania białych ksiąg bezpieczeństwa, w których omawiane są najważniejsze kwestie z zakresu bezpieczeństwa i obronności Australii. W dokumencie tego rodzaju przygotowanym w 2013 r. zapisano, że Australia „winszuje chińskiego wzrostu”, a jej rząd ,nie podchodzi do Chin jak do rywala”. Zaakcentowane zostały też jednak obawy i niepewność, jakie niesie za sobą szybki rozwój potencjału militarnego i wzrost asertywności Państwa Środka, głównie wobec krajów basenu Morza Południowochińskiego. W związku z tym opowiedziano się za pokojową współpracą między globalnymi i regionalnymi partnerami w celu utrzymania pokoju i bezpieczeństwa ${ }^{18}$. Premier Rudd stwierdził, że najlepszą opcją dla Australii i Chin jest wypracowanie modelu, który nazwał konstruktywnym realizmem - wspólnym celem. Wymagałoby to określenia najpoważniejszych różnic dzielących oba państwa i opracowania strategii, która w jak największym stopniu ograniczyłaby ich negatywne skutki. Jednocześnie rządy miałyby określić obszary współpracy i wspólne problemy, które można by rozwiązywać na zasadzie partnerstwa i w oparciu o wzrost zaufania, co mogłoby się przyczynić do rozwoju współpracy w całym regionie i ograniczać stosowanie gróźb i wymuszeń ${ }^{19}$.

W białej księdze bezpieczeństwa wydanej w 2016 r. Australia opowiedziała się za pogłębianiem współpracy z Chinami w zakresie bezpieczeństwa i obronności. Dotyczy to przede wszystkim strategicznego dialogu w tych obszarach, dyskusji w zakresie polityki strategicznej, prac grup roboczych, wspólnych działań na morzu i uczestnictwa w operacjach pokojowych. Jednocześnie Canberra wezwała w tym dokumencie Pekin do większej

17 Strong and secure...

182013 Defence White Paper, Australian Government Department of Defence, Canberra 2013, s. 11, dostępny w internecie [dostęp: 5 II 2019]: <http://www.defence.gov.au/whitepaper/2013/docs/WP_2013_web.pdf>.

19 M. Lanteigne, Chinese foreign policy. An introduction, 3 ed., Routledge, London-New York 2016, s. 150. 
transparentności w zakresie polityki bezpieczeństwa i obrony. Aby zachęcić Chiny do pozytywnych zmian w tym obszarze, zaproponowała zwiększenie poziomu wymiany personelu wojskowego, intensyfikację wspólnych ćwiczeń wojskowych, wzmożoną współpracę w zakresie misji ratowniczych i humanitarnych oraz wspólne zwalczanie piractwa morskiego ${ }^{20}$.

Jak dotąd strategiczna współpraca Chin i Australii w obszarze bezpieczeństwa i obronności jest bardzo ograniczona. Nieporównywalnie lepiej wygląda to natomiast na linii Canberra-Waszyngton; Australia korzysta m.in. ze wsparcia Stanów Zjednoczonych w zakresie wzmacniania własnego systemu bezpieczeństwa i obronności. Można powiedzieć, że o ile USA pełnią rolę światowego żandarma, o tyle Australia jawi się jako jego zastępca w Oceanii, a w pewnym stopniu nawet szerzej - w regionie Azji i Pacyfiku. Wzrost aktywności wojskowej Canberry na tym obszarze i próba odgrywania większej roli w kwestii jego bezpieczeństwa dostrzeżone zostały w strategii bezpieczeństwa Chin z 2019 r. ${ }^{21}$

Australia stoi przed poważnym dylematem strategicznym. $Z$ jednej strony, aby zapewnić sobie bezpieczeństwo ekonomiczne i stabilny rozwój gospodarczy, intensywnie pogłębia współpracę z szybko rozwijającymi się Chinami, z drugiej jednak żywi duże obawy co do wzrostu ich potęgi. Czyni w związku z tym starania, by zabezpieczyć się na ewentualność zmiany polityki Państwa Środka na bardziej asertywną i ekspansjonistyczną. W celu uniknięcia nadmiernego uzależnienia gospodarczego od Chin próbuje dywersyfikować partnerów handlowych, jednak jej dotychczasowe działania w tym zakresie są dalece niewystarczające ${ }^{22}$. Aby zwiększyć poziom bezpieczeństwa militarnego, Australia zacieśnia sojusz ze Stanami Zjednoczonymi. Jednocześnie odczuwa jednak coraz większą presję wynikającą z rywalizacji między Waszyngtonem i Pekinem. Jako średnie mocarstwo, politycznie i militarnie blisko związane z USA, a gospodarczo - z ChRL, coraz wyraźniej balansuje, a jednocześnie próbuje pośredniczyć między dwoma potężnymi partnerami. Władze Australii mają nadzieję, że między hegemonem i pretendentem nie dojdzie do klasycznej

202016 Defence White Paper, Australian Government Department of Defence, Canberra 2016, s. 42-43, 133, dostępny w internecie [dostęp: 5 II 2019]: <http://www.defence.gov. $\mathrm{au} /$ WhitePaper/Docs/2016-Defence-White-Paper.pdf>.

21 China's national defense in the new era, The State Council Information Office of the People's Republic of China, Beijing, July 2019, dostępny w internecie [dostęp: 17 X 2019]: $<$ http://www.xinhuanet.com/english/download/whitepaperonnationaldefenseinnewera.doc $>$.

22 N. Laurenceson, Trade provides the ballast for relations with China, „Australian Institute of International Affairs" [online], 4 VII 2019 [dostęp: 5 II 2019], dostępny w internecie: $<$ http://www.internationalaffairs.org.au/australianoutlook/trade-provides-the-ballastfor-relations-with-china/>. 
rywalizacji w postaci gry o sumie zerowej. Canberra liczy, że uda jej się pomóc obu państwom w odnalezieniu wspólnych celów i skupieniu się na nich, co umożliwiłoby wypracowanie względnie dobrych relacji ${ }^{23}$.

Należy podkreślić, że współpracę między Australią i Chinami utrudniają głębokie różnice ideologiczne oraz inne spojrzenie na kwestie międzynarodowego pokoju i bezpieczeństwa. Canberra próbuje wpływać na Pekin, by zbliżał swoją politykę do zachodnich standardów demokratycznego państwa prawa. Zazwyczaj jednak tego rodzaju działania nie spotykają się w Chinach z dobrym odbiorem, a wyjątkowo negatywne emocje budzi próba wymuszania na nich zmiany podejścia do kwestii praw człowieka. Postawa Australii wobec Państwa Środka określana jest czasem przez obserwatorów mianem Zhengyou, czyli krytycznego przyjaciela. Polega na budowaniu partnerstwa, a jednocześnie otwartej krytyce za łamanie praw człowieka. Upomnienia te mają nakłonić Pekin do zmiany polityki, co w ostateczności ma się przysłużyć zarówno Chinom, jak i całej społeczności międzynarodowej. W ostatnich latach obserwujemy jednak większą wstrzemięźliwość władz Australii na tym polu² ${ }^{24}$. Wyciszenie krytyki może być spowodowane szybkim wzrostem potęgi Chin, które sukcesywnie rozszerzają swoje wpływy w Australii. Zmniejszenie intensywności krytyki nie oznacza jednak jej zaprzestania, a przykładem jest podpisanie w lipcu 2019 r. przez ambasadora Australii przy ONZ listu potępiającego Chiny za niehumanitarne traktowanie Ujgurów oraz nawołującego do zamknięcia obozów reedukacyjnych w regionie Sinkiang. Towarzyszyła temu zdecydowana krytyka działań Pekinu przez przedstawicieli australijskiego rządu ${ }^{25}$.

Wzrost potęgi Państwa Środka dostrzega także społeczeństwo, co pokazują badania opinii publicznej. W sondażu przeprowadzonym w 2018 r. przez Lowy Institute 82 proc. Australijczyków upatrywało w Chinach bardziej partnera gospodarczego niż zagrożenie militarne. Jednocześnie jednak aż 46 proc. badanych uznało za prawdopodobne, że w ciągu dwudziestu lat państwo to może zagrażać Australii wojskowo. 81 proc. ankietowanych uważało też, że możliwe jest utrzymywanie dobrych relacji jednocześnie z Chinami i Stanami

23 Y. Hao, D. Zweig, Introduction: Sino-US energy competition in resource rich states, [w:] Sino-US energy triangles. Resource diplomacy under hegemony, ed. D. Zweig, Y. Hao, Routledge, London-New York 2016, s. 7.

24 T. Okraska, Stosunki australijsko-chińskie. Historia, stan obecny, perspektywy, [w:] Australia w XX i XXI wieku. Polityka, historia i kultura, red. A. Kandzi-Poździał, J. Siekiera, Wydawnictwo Uniwersytetu Śląskiego, Katowice 2016, s. 111-112.

25 E. Collinson, The Australian government on Xinjiang (October 2019 update), „Australia-China Relations Institute" [online], 15 X 2019 [dostęp: 10 II 2019], dostępny $\mathrm{w}$ internecie: <https://www.australiachinarelations.org/content/australian-governmentxinjiang-october-2019-update>. 
Zjednoczonymi, choć aż 77 proc. zgodziło się ze stwierdzeniem, że w przyszłości dojdzie do konfliktu między tymi państwami, a Australia zostanie do niego wciągnięta $\mathrm{z}$ racji sojuszu $\mathrm{z}$ Waszyngtonem. W tym samym badaniu 72 proc. Australijczyków stwierdziło, że ich rząd godził się na zbyt wiele inwestycji z Chin, co miało zagrażać bezpieczeństwu ekonomicznemu państwa, podczas gdy jeszcze w roku 2014, opinię taką wyraziło 56 proc. badanych. Dalszy rozwój armii ChRL i coraz większa asertywność Pekinu wobec sąsiadów będą powodować wzrost obaw Australijczyków co do potencjalnego zagrożenia militarnego ze strony $\mathrm{Chin}^{26}$.

\section{Wspólpraca Australii i Stanów Zjednoczonych w kontekście wzrostu potęgi Chin}

Dynamiczny wzrost potęgi Chin oraz większa aktywność jej marynarki wojennej na wodach otaczających sojuszników i partnerów Stanów Zjednoczonych w regionie Azji i Pacyfiku, ale także zagrożenie ze strony niestabilnej, sojuszniczej wobec Pekinu Korei Północnej powodują, że Amerykanie wzmacniają swój potencjał wojskowy w regionie i szukają baz, z których mogliby swobodnie korzystać27. Pod koniec 2011 r. prezydent Barack Obama (I 2009 - I 2017) zapowiedział $\mathrm{w}$ polityce zagranicznej Stanów Zjednoczonych strategiczny zwrot ku Azji (pivot to Asia). Polega on na wzmocnieniu pozycji wojskowej USA w regionie Azji i Pacyfiku oraz zacieśnieniu więzi polityczno-militarnych z położonymi tam państwami, głównie Australią, Japonią, Koreą Południową, Filipinami, Singapurem i Wietnamem. Pekin słusznie odebrał to jako zapowiedź polityki powstrzymywania wzrostu potęgi Chin w regionie i wyraził poważne zaniepokojenie takim podejściem ${ }^{28}$. Państwu Środka znacznie trudniej jest wzmacniać współpracę wojskową w regionie, ponieważ jego najbliżsi partnerzy, tj. Korea Północna i Mjanma, są znacznie słabsi, a przede wszystkim prowadzą kontrowersyjną politykę wewnętrzną i międzynarodową ${ }^{29}$.

26 2018 Lowy Institute Poll, ,Lowy Institute” [online], 20 VI2018 [dostęp: 10 II 2019], dostępny w internecie: <https://www.lowyinstitute.org/publications/2018-lowy-institute-poll $>$.

27 R. Kamiński, Wybrane aspekty polityki zagranicznej Australii u progu XXI wieku, [w:] Wielka Brytania i Wspólnota u progu XXI wieku. Przeszłość - teraźniejszość - perspektywy, red. I. Penier, Wydawnictwo Uniwersytetu Łódzkiego, Łódź 2014, s. 37-38.

28 M. Lanteigne, Chinese foreign policy..., s. 108.

29 S. Zhao, China and America: showdown in the Asia-Pacific?, [w:] Conflict and cooperation in Sino-US relations. Change and continuity, causes and cures, ed. J.M.F. Blanchard, S. Shen, Routledge, London-New York 2015, s. 82. 
Działania Stanów Zjednoczonych wobec regionu Azji i Pacyfiku są zgodne z oczekiwaniami Australii, z którą od 1951 r. formalnie łączy je sojusz wojskowy w ramach Paktu Bezpieczeństwa Pacyfiku (Pacific Security Treaty), znany także pod akronimem ANZUS, utworzonym od pierwszych liter państw członkowskich: Australii, Nowej Zelandii i USA. W białych księgach bezpieczeństwa z 2013 i 2016 r. Canberra podkreśla znaczenie Waszyngtonu jako jej najważniejszego partnera strategicznego i akcentuje potrzebę poszerzania i pogłębiania sojuszniczej współpracy, także w zakresie zapewniania bezpieczeństwa w regionie Azji i Pacyfiku. Australia wspiera w związku z tym wysiłki USA w rebalansowaniu ich siły militarnej w kierunku tego regionu ${ }^{30}$. Dla Stanów Zjednoczonych pogłębiona współpraca militarna $\mathrm{z}$ Australią jest natomiast jednym z istotniejszych elementów wzmacniania swojej pozycji w regionie.

Podczas spotkania Baracka Obany z Julią Gillard w listopadzie 2011 r. amerykański prezydent zaproponował stałą obecność wojsk USA w Australii, zapowiadając jednocześnie możliwość rozlokowania ich w którymś z północnych portów między 2012 a 2017 r. Amerykanie mieli współpracować z żołnierzami sojuszniczych i partnerskich armii z regionu Azji i Pacyfiku, $\mathrm{m}$.in. biorąc udział $\mathrm{w}$ wielonarodowych ćwiczeniach oraz operacjach humanitarnych i ratowniczych ${ }^{31}$. Oświadczenie Obamy było pierwszą konkretną propozycją złożoną przez amerykańską administrację w ramach polityki zwrotu ku Azji jakiemukolwiek państwu. Władze Chin zareagowały na nią negatywnie, przestrzegając, że jej realizacja przyczyni się do destabilizacji regionu ${ }^{32}$. Propozycja Waszyngtonu została jednak zaakceptowana przez Canberrę i zrealizowana w kolejnych latach. Obecnie 2,5 tys. amerykańskich marines stacjonuje w Darwin na zasadzie stałej rotacji.

Stany Zjednoczone i Australia rozwinęły również inne formy współpracy w obszarze bezpieczeństwa i obronności. W czerwcu 2012 r. prezydent Obama zapowiedział, że do 2020 r. amerykańska marynarka wojenna zmieni proporcje stacjonowania swojej floty na Pacyfiku i Atlantyku z 50:50 proc. na 60:40 proc. na korzyść Oceanu Spokojnego. Przemieszczane na ten akwen okręty mają korzystać z portów państw sojuszniczych i partnerskich, w tym Australii. Waszyngton i Canberra zdecydowały m.in. o zwiększeniu dostępu amerykańskich sił do baz w Australii, szczególnie morskiej bazy Stirling i kilku lotnisk. Australijski rząd zgodził się również, by Amerykanie przemieścili

302013 Defence White Paper..., s. 56; 2016 Defence White Paper.., s. 15.

31 A.M. Denmark, US strategic rebalancing and the rise of China, [w:] New dynamics..., s. $19-20$.

32 M. Lanteigne, Chinese foreign policy..., s. 140. 
na terytorium kraju znaczne zapasy, m.in. paliwa i amunicji. Trwają również rozmowy na temat możliwości wykorzystywania przez USA zlokalizowanych na Oceanie Indyjskim w odległości 1100 km od Sumatry Wysp Kokosowych, które są terytorium zależnym Australii. Mają one istotne znaczenie strategiczne ze względu na sąsiedztwo ze szlakami transportowymi na Oceanie Indyjskim i Pacyfiku. Amerykanie planują zlokalizować tam bazę bezzałogowych statków obserwacyjnych ${ }^{33}$. Marynarka USA włączyła ponadto australijski okręt wojenny do swojej grupy uderzeniowej lotniskowca. Oba państwa rozszerzyły także współpracę $\mathrm{w}$ zakresie wzmacniania bezpieczeństwa w cyberprzestrzeni i obserwacji kosmosu ${ }^{34}$, a Australia zwiększyła zaangażowanie w rozwój amerykańskich obiektów komunikacji wojskowej w regionie Azji i Pacyfiku ${ }^{35}$.

W Chinach wzmacnianie współpracy wojskowej Stanów Zjednoczonych z Australią i innymi państwami regionu obserwowane jest z dużym niepokojem. Zacieśnianie australijsko-amerykańskiego sojuszu wojskowego wyszczególnione zostało w strategii bezpieczeństwa Chin z 2019 r. ${ }^{36}$ i odbierane jest przez Pekin jako przejaw postawy antychińskiej, co obniża poziom zaufania między ChRL i USA oraz amerykańskimi sojusznikami i partnerami z regionu, w tym Australią̧ ${ }^{37}$. Chińczycy obawiają się szczególnie tego, że zacieśniana współpraca strategiczna Stanów Zjednoczonych z Australią, Japonią, Koreą Południową, Filipinami i Singapurem, a w pewnym stopniu również z innymi państwami, może prowadzić do sformalizowania regionalnego sojuszu pod amerykańskim przywództwem. Promują wobec tego strategiczną współpracę $\mathrm{w}$ regionie $\mathrm{w}$ formie wspólnot bezpieczeństwa, które nie mają być strukturami sojuszniczymi balansującymi siły rywala, ale opierać się o strategiczne interesy, pokojową współpracę oraz poszanowanie suwerenności i neutralności państw zaangażowanych i trzecich ${ }^{38}$. Przykładowo od 2005 r. w ramach Szczytu Azji Wschodniej (East Asia Summit - EAS) Chiny współpracują z piętnastoma państwami, głównie z Azji. Wśród członków EAS znajduje

33 E. Goh, Evaluating Southeast Asian responses to China's rise: the vital context of managing great power resurgence, [w:] China's power..., s. 208.

34 P.C. Saunders, China's rising power and the U.S. rebalance to Asia: implications for U.S.-China relations, [w:] China's power..., s. 96.

35 R.S. Ross, Chinese security policy. Structure, power and politics, Routledge, LondonNew York 2009, s. 9.

36 China's national defense...

37 E. Goh, Evaluating..., s. 208.

38 M. Lanteigne, Chinese foreign policy..., s. 119-120. 
się Australia, ale także Stany Zjednoczone, które początkowo nie zostały zaproszone do tego grona, jednak ostatecznie dołączyły do niego w listopadzie $2011 \mathrm{r}$.

Istotną okolicznością australijsko-amerykańskiej współpracy wojskowej w kontekście stosunków z Chinami jest problem Tajwanu. Oficjalnie Canberra uznaje tę wyspę za prowincję ChRL, jednak sprzeciwia się stosowaniu przez Pekin nacisków i gróźb wobec Tajpej. W 2004 r. minister spraw zagranicznych Alexander Downer (III 1996 - XII 2007) ogłosił, że w przypadku wybuchu amerykańsko-chińskiego konfliktu zbrojnego o Tajwan Australia może nie wesprzeć USA ${ }^{39}$. Wypowiedź ta warunkowana była m.in. rosnącym znaczeniem Chin dla bezpieczeństwa ekonomicznego Australii. Spotkała się jednak ze zdecydowaną odpowiedzią Departamentu Stanu, który zażądał wyjaśnień. Waszyngton stwierdził, że zobowiązania sojusznicze w ramach ANZUS jednoznacznie obligują Canberrę do udzielenia pomocy w przypadku takiego konfliktu. Ostatecznie premier John Howard (III 1996 - XII 2007) zmuszony był odciąć się od kontrowersyjnej wypowiedzi swojego ministra ${ }^{40}$. W późniejszym okresie rząd Australii starał się unikać poruszania tego problemu w relacjach z Waszyngtonem i Pekinem. Kwestia Tajwanu nie została też wspomniana w SBN z 2013 r. ani w białych księgach bezpieczeństwa z 2013 i 2016 r.

W Australii pojawiają się też jednak głosy przeciwne zacieśnianiu współpracy wojskowej ze Stanami Zjednoczonymi. Przykładowo były premier Malcolm Fraser (IX 1975 - III 1983) uważa, że działania Amerykanów na rzecz utrzymania światowej dominacji doprowadzą prawdopodobnie do wojny. Wiara, że bezpieczeństwo można sobie zapewnić, wyświadczając przysługi hegemonowi, jest jego zdaniem bezpodstawna, a przyjęcie takiej postawy prowadzi do ograniczenia suwerenności. Znacznie bardziej skłaniałby się do współpracy z Chinami, które nie przejawiają, jak twierdzi, tego rodzaju nacjonalizmu co USA, Rosja i mocarstwa europejskie ${ }^{41}$. Takie głosy są jednak w mniejszości, a gros elit politycznych i społeczeństwa Australii popiera zacieśnianie polityczno-wojskowej współpracy ze Stanami Zjednoczonymi na wypadek ewentualnego zagrożenia ze strony rosnących w siłę Chin. Niemniej Canberra dystansuje się od zdecydowanej postawy

39 J. Canrong, A changing Sino-American relationship in a changing world, [w:] Sino-American relations. Challenges ahead, ed. Y. Hao, Routledge, London-New York 2016, s. 67.

40 M. Herberg, US energy security strategy and China's energy diplomacy, [w:] Sino-US energy..., s. 66-67.

$41 \mathrm{M}$. Tai, US-China relations in the twenty-first century. A question of trust, Routledge, London-New York 2015, s. 147. 
administracji Donalda Trumpa wobec Pekinu; nie określa Chin jako strategicznego rywala i nie chce uczestniczyć w wojnie celnej przeciwko nim ${ }^{42}$.

Współpraca australijsko-chińska w obszarze wojskowości praktycznie nie istnieje. Wyjątki stanowią na przykład australijsko-chińsko-amerykańskie ćwiczenia wojskowe, które po raz pierwszy odbyły się w październiku 2014 r., albo współpraca między jednostkami Australii i Chin przy poszukiwaniu zaginionego samolotu malezyjskich linii lotniczych (lotu MH370) na południu Oceanu Indyjskiego. Działania te mają jednak bardzo ograniczony wymiar, co potwierdza, że pozycja Stanów Zjednoczonych jako strategicznego partnera Australii w dziedzinie bezpieczeństwa i obronności jest niezachwiana.

\section{Postawa Australii wobec asertywnych działań Chin w regionie Azji i Pacyfiku}

Poważnym problemem dla Australii są rosnące napięcia między Chinami a państwami Stowarzyszenia Narodów Azji Południowo-Wschodniej (Association of Southeast Asian Nations - ASEAN) wokół wysp na Morzu Południowochińskim. W lipcu 2011 r. Stany Zjednoczone, Australia i Japonia po raz pierwszy przeprowadziły wspólne morskie ćwiczenia wojskowe na tym akwenie, w pobliżu Brunei. Miały one zademonstrować ścisłe związki sojusznicze między biorącymi w nich udział państwami oraz siłę i spójność działań na wypadek wzrostu aktywności militarnej Chin w regionie ${ }^{43}$. W lipcu 2016 r. Stały Trybunał Arbitrażowy w Hadze orzekł, że ChRL nie może rościć sobie historycznych ani żadnych innych praw do Morza Południowochińskiego ${ }^{44}$. Canberra, wspólnie z Waszyngtonem i Tokio, wezwała wtedy Pekin do przestrzegania orzeczenia, uznając je za rozstrzygające spór. W kolejnych latach na spornym akwenie dochodziło jednak do incydentów między okrętami marynarki wojennej Chin i Australii oraz Chin i USA. Władze Australii zdecydowanie krytykują instalowanie przez Chiny systemów rakietowych na zlokalizowanych tam wyspach. Z ostrą reakcją Canberry spotkało się na przykład przemieszczenie rakiet na wyspy Nansha w maju 2018 r. Australijczycy

42 J. Power, US and Australia grow apart on China, behind the smiles and handshakes, „South China Morning Post” [online], 20 IX 2019 [dostęp: 17 X 2019], dostępny w internecie: <https://www.scmp.com/week-asia/politics/article/3028141/us-and-australia-growapart-china-behind-smiles-and-handshakes $>$.

$43 \mathrm{H}$. Akutsu, The changing security dynamics in Northeast Asia and the US alliances with Japan and South Korea: toward synchronization, [w:] China's power..., s. 276-277.

44 K.H.-Y. Tseng, Rethinking South China Sea disputes. The untold dimensions and great expectations, Routledge, London-New York 2017, s. 164-165. 
protestują również przeciwko budowaniu przez Chiny sztucznych wysp i nielegalnemu wyznaczaniu wokół nich obszarów wód terytorialnych. Zarówno politycy, jak i wysocy rangą oficerowie marynarki wojennej Australii nagminnie wzywają Pekin do poszanowania wolności żeglugi i podporządkowania się zasadom prawa morskiego. Wyspiarski charakter Australii powoduje, że sprawuje ona jurysdykcję nad ogromnymi obszarami morskimi oraz różnego typu surowcami biologicznymi i naturalnymi zlokalizowanymi w wodzie i pod jej powierzchnią ${ }^{45}$. Próby zmiany jurysdykcji obszarów morskich przez ich siłowe zawłaszczanie stanowią więc dla tego państwa poważne zagrożenie, dlatego musi na nie zdecydowanie reagować.

W listopadzie 2013 r. Pekin zdecydował się ustanowić Strefę Identyfikacji Obronnej Morza Wschodniochińskiego (East China Sea Air Defense Identification Zone - ADIZ). Obejmuje ona znaczną część akwenu, w tym kontrolowane przez Japonię wyspy Senkaku, które są przedmiotem sporu między Japonią, Chinami i Tajwanem. Canberra zdecydowanie skrytykowała Pekin i wezwała go do powstrzymania się od wszelkich jednostronnych działań, które przyczyniają się do destabilizacji sytuacji w regionie. Następnie premier Tony Abbott zaprosił do Canberry premiera Shinzō Abe (IX 2006 - IX 2007, od XII 2012), a podczas spotkania nazwał Japonię najlepszym przyjacielem Australii w Azji ${ }^{4}$. Równie zdecydowanie zareagował Pekin, który wezwał Canberrę do rewizji stanowiska, aby nie szkodziło ono bilateralnym relacjom obu państw. Rząd Abbota tylko w pewnym stopniu złagodził kurs, wyrażając nadzieję, że kontrowersje wokół ADIZ nie będą miały negatywnego wpływu na dobrze rozwijające się stosunki gospodarcze między Australią i Chinami.

W Australii duży niepokój budzi szybka rozbudowa i modernizacja floty wojennej ChRL oraz jej ekspansja. Aby zwiększyć potencjał wojskowy na Pacyfiku, Chiny rozwijają program budowy lotniskowców. Jego początki wiązały się z zakupem poradzieckich okrętów Wariag, Minsk i Kijew oraz kadłuba wycofanego z użytkowania australijskiego HMAS Melbourne. W 2012 r. do służby wszedł pierwszy chiński lotniskowiec, Liaoning, którego budowę zaczęto w Związku Radzieckim pod nazwą Riga, a później Wariag. Obecnie Chiny budują własne lotniskowce, ale z uwagi na wielkość przedsięwzięcia ich wykorzystanie planowane jest dopiero za około dekadę. Dużo bardziej zaawansowany i rozwinięty jest chiński program budowy okrętów

45 P.K.-h. Yu, Ocean governance, regimes, and the South China Sea issues. A one-dot theory interpretation, Springer, New York-Singapore 2015, s. 42.

46 M. Lanteigne, Chinese foreign policy..., s. 175. 
podwodnych typu 94 i 96 oraz atomowych okrętów podwodnych typu 93 i 95. Chiny realizują także zaawansowane programy budowy okrętów nawodnych różnego typu, w tym nowoczesnych wersji niszczycieli typu 051 i 052. Poszczególne jednostki pływające wyposażane są w pociski nowej generacji, oferujące nowatorskie programy rakietowe i torpedowe. Przedsięwzięcia te budzą poważne obawy Australii, ponieważ budowany potencjał wykorzystywany będzie zarówno na przyległych do Chin Morzu Wschodniochińskim i Morzu Południowochińskim, jak i na innych akwenach Pacyfiku i Oceanu Indyjskiego, w tym wodach otaczających Australię ${ }^{47}$. Canberra obawia się m.in. tego, że w przyszłości Pekin będzie próbował przejąć kontrolę nad głównymi morskimi szlakami handlowymi w regionie Azji i Pacyfiku.

Australia dysponuje flotą wojenną średniej wielkości, ale stanowi istotną siłę w regionie Azji i Pacyfiku. W związku z szybkim rozwojem floty ChRL w drugiej dekadzie XXI w. znacząco przyspieszyła program modernizacji i wzmocnienia własnych sił morskich. W 2014 i 2015 r. do użytku weszły dwie nowe potężne jednostki amfibijne klasy Canberra. Obecnie opracowywane i wdrażane są różne programy budowy nowych okrętów nawodnych i podwodnych, ze sztandarowymi niszczycielami rakietowymi typu Hobart, fregatami typu Hunter i łodziami podwodnymi typu Collins ${ }^{48}$. Podczas kampanii wyborczej w sierpniu 2013 r. Kevin Rudd wystąpił z postulatem przemieszczenia na północ okrętów wojennych, które w większości stacjonują na południu państwa, głównie w porcie w Sydney. Ocenił, że gdyby podjęto taką decyzję, proces ten mógłby zostać zakończony do 2030 r., co ułatwiłoby wprowadzenie do modernizowanego portu w Sydney nowych jednostek, w tym desantowców typu Canberra i niszczycieli typu Hobart ${ }^{49}$.

Poważnym problemem dla bezpieczeństwa Australii jest szpiegostwo ze strony ChRL. Przykładowo w 2013 r. telewizja ABC ujawniła, powołując się na anonimowego pracownika służb specjalnych, że hakerzy z Chin wykradli plany nowej siedziby australijskiego wywiadu. Władze w Canberze nie zdementowały tych informacji, określając je jedynie jako nieprecyzyjne $^{50}$. Obawy o szpiegostwo spowodowały, że w sierpniu 2018 r. rząd zablokował możliwość udziału chińskich przedsiębiorstw telekomunikacyjnych Huawei i ZTE w rozwoju australijskiej sieci komórkowej 5G,

47 R.P. Rajagopalan, India-China relations: a new turn under Xi Jinping?, [w:] Chinese foreign policy under Xi, ed. H.T. Boon, Routledge, London-New York 2017, s. 99.

48 R.A. Bitzinger, China's military buildup: regional repercussions, [w:] China's power.., s. 48.

49 T. Okraska, Stosunki..., s. 114.

50 Tamże, s. 115. 
która ma być elementem infrastruktury krytycznej państwa. Chińskie prawo zobowiązuje przedsiębiorstwa do przekazywania rządowi informacji, co może być wykorzystywane w działalności szpiegowskiej. Huawei broniło się przed zarzutami, wskazując, że jest prywatnym przedsiębiorstwem działającym niezależnie od chińskiego rządu, jednak jego argumentacja nie przekonała strony australijskiej ${ }^{51}$. Z kolei w październiku 2019 r. minister spraw wewnętrznych Australii Peter Dutton (od XII 2017) oskarżył KPCh o zaaranżowanie w Australii serii cyberataków ukierunkowanych na kradzież własności intelektualnej i ograniczenie wolności słowa. Pekin określił te zarzuty jako nieracjonalne, szokujące i bezzasadne ${ }^{52}$.

W 2017 r. w Australii rozgorzały kontrowersje wokół problemu nacisków Pekinu na australijskich polityków i zmuszania studiujących w kraju Chińczyków do zdawania raportów rodzimym służbom wywiadowczym. Śledztwa i debata publiczna w tym zakresie pogłębiły nieufność Australijczyków wobec komunistycznych władz ChRL. W czerwcu 2018 r. Canberra wprowadziła w związku z tym nowe prawo, którego celem było ograniczenie wpływów zagranicznych w Australii. Wzmocniło ono kontrwywiad, zakazało dotacji dla partii politycznych ze strony zagranicznych przedsiębiorstw i zmusiło ich przedstawicieli do deklarowania realizowanych działań. Ministerstwo Spraw Zagranicznych Chin z oburzeniem zareagowało na te zmiany, wzywając Canberrę do porzucenia zimnowojennych praktyk na rzecz polepszenia współpracy opartej na wzajemnym szacunku i równości ${ }^{53}$.

\section{Zakończenie}

Wzrost potęgi Chin, a szczególnie programy zbrojeniowe, wzbudzają w Australii obawy, że w przyszłości potencjał ten może zostać wykorzystany przeciwko jej ważnym interesom, a nawet bezpośrednio zagrozić

51 G. Wyeth, Why did Australia block Huawei, ZTE from 5 G roll out?, ,The Diplomat” [online], 28 VIII 2018 [dostęp: 18 II 2019], dostępny w internecie: <https://thediplomat. com/2018/08/why-did-australia-block-huawei-zte-from-5g-roll-out/>.

52 Australian PM Scott Morrison slammed for ,doing Beijing's work for it” and mishandling China ties, „South China Morning Post” [online], 14 X 2019 [dostęp: 17 X 2019], dostępny w internecie: <https://www.scmp.com/news/asia/australasia/article/3032789/ australian-pm-scott-morrison-slammed-doing-beijings-work-it>.

53 J. Fang, J. Kilbride, T. Shelton, Chinese-Australian relations have had a rollercoaster year in 2018, „ABC News” [online], 27 XII 2018 [dostęp: 18 II 2019], dostępny w internecie: <https://www.abc.net.au/news/2018-12-27/chinese-australian-relations-have-hada-rollercoaster-year/10638590>. 
bezpieczeństwu państwa. Niepokój potęgują rosnące ambicje regionalne Państwa Środka i utrzymywany system autorytarny. Mimo wzrostu asertywności Pekinu w regionie w jego polityce wciąż nie ma przesłanek sugerujących, że Chiny mogłyby użyć siły bezpośrednio przeciwko Australii. Może to jednak ulec zmianie, szczególnie gdyby rząd w Canberze aktywnie wsparł Stany Zjednoczone lub inne mocarstwo w rywalizacji o strategiczny prymat $\mathrm{w}$ regionie Azji i Pacyfiku ${ }^{54}$. Z tego względu Australia podejmuje szereg działań mających ją przygotować na ten najgorszy scenariusz. Hipoteza badawcza została potwierdzona. Australia słusznie koncentruje się na zwiększaniu własnego potencjału wojskowego oraz pogłębianiu wieloaspektowej współpracy z sojusznikami i partnerami z regionu Pacyfiku. Konieczne jest jednak wzmożenie wysiłków i dotyczy to zarówno obszaru bezpieczeństwa, jak i gospodarczego, w ramach którego niezbędna jest większa dywersyfikacja partnerów. Jednocześnie Australia próbuje rozwijać partnerskie stosunki z Chinami, co daje jej szereg profitów, szczególnie w obszarze gospodarczym. Optymalnym scenariuszem zabezpieczenia strategicznych interesów Australii byłaby budowa bliskich relacji z Chinami przy jednoczesnym pogłębianiu sojuszu ze Stanami Zjednoczonymi. Będzie to jednak możliwe jedynie wówczas, gdy nie nasili się rywalizacja między tymi mocarstwami. Australia powinna oddziaływać na USA i ChRL, wskazując im wspólne interesy i przyczyniając się do łagodzenia istniejących między nimi napięć.

Mimo że gospodarczo Australia jest coraz bardziej zależna od Chin, to w wymiarze polityczno-wojskowym jej strategicznym sojusznikiem pozostają Stany Zjednoczone. Wynika to m.in. ze wspólnych obaw o kierunki przyszłej polityki dynamicznie rosnącego w siłę Państwa Środka, ale również tradycji sojuszniczych, wspólnych doświadczeń wojskowych w postaci operacji i ćwiczeń, wspólnych przedsięwzięć w zakresie obronności i korzystania przez Australię z amerykańskich technologii wojskowych. Obecnie nie widać dla Canberry alternatywy wobec pogłębiania strategicznego sojuszu z Waszyngtonem ${ }^{55}$. Zależy jej jednak na tym, by w Pekinie nie postrzegano Australii jako elementu amerykańskiego systemu okrążania i ograniczania wpływów Chin. Dla rządu w Pekinie proamerykańska postawa partnera jest jednak czytelna i powoduje coraz częstsze napięcia w stosunkach dwustronnych.

54 H. White, How to defend Australia, La Trobe University Press, Melbourne 2019, s. 32.

55 R. Kamiński, Wybrane aspekty..., s. 37-38. 
Australijscy eksperci zdają sobie sprawę, że Chiny są zdeterminowane do wypchnięcia amerykańskich wpływów z Azji, a w dłuższej perspektywie trzeba się liczyć, że ustanowiony przez Amerykanów i korzystny dla Australii porządek międzynarodowy dobiegnie końca ${ }^{56}$. W sytuacji wyraźnego wzrostu napięć między USA i ChRL Australia może być postawiona przed jednoznacznym wyborem, na którym z mocarstw się oprzeć. Decyzja wydaje się dość oczywista, jednak okupiona zostanie utratą części profitów wynikających z bliskiej współpracy gospodarczej z Państwem Środka, a może też sprowadzić na Australię bezpośrednie zagrożenie z jego strony. W związku $\mathrm{z}$ tym rząd $\mathrm{w}$ Canberze musi w większym stopniu skupiać się na pogłębianiu wielowymiarowej współpracy z innymi państwami azjatyckimi i umacniać w ten sposób własne bezpieczeństwo. Jednocześnie Australia powinna kontynuować rozwój współpracy z partnerami z Oceanii, m.in. po to, żeby ograniczyć rozwój wpływów Chin na tym obszarze, co zapobiegnie otoczeniu państwa z północy i ze wschodu.

\section{Bibliografia}

2013 Defence White Paper, Australian Government Department of Defence, Canberra 2013, dostępny w internecie [dostęp: 5 II 2019]: <http://www.defence.gov.au/whitepaper/2013/ docs/WP_2013_web.pdf $>$.

2016 Defence White Paper, Australian Government Department of Defence, Canberra 2016, dostępny w internecie [dostęp: 5 II 2019]: <http://www.defence.gov.au/WhitePaper/ Docs/2016-Defence-White-Paper.pdf>.

2018 Lowy Institute Poll, „Lowy Institute” [online], 20 VI 2018 [dostęp: 10 II 2019], dostępny w internecie: $<$ https://www.lowyinstitute.org/publications/2018-lowy-institute-poll>.

Akutsu H., The changing security dynamics in Northeast Asia and the US alliances with Japan and South Korea: toward synchronization, [w:] China's power and Asian security, ed. M. Li, K. M. Kemburi, Routledge, London-New York 2015.

Asia responds to its rising powers: China and India, ed. A.J. Tellis, T. Tanner, J. Keogh, National Bureau of Asian Research, Seattle 2011.

Australia w XX i XXI wieku. Polityka, historia i kultura, red. A. Kandzi-Poździał, J. Siekiera, Wydawnictwo Uniwersytetu Śląskiego, Katowice 2016.

Australian PM Scott Morrison slammed for ,doing Beijing's work for it” and mishandling China ties, „South China Morning Post” [online], 14 X 2019 [dostęp: 17 X 2019], dostępny w internecie: <https://www.scmp.com/news/asia/australasia/article/3032789/ australian-pm-scott-morrison-slammed-doing-beijings-work-it>.

56 J. Molan, Australia needs a clear national security strategy, „The Strategist” [online], 12 X 2018 [dostęp: 18 II 2019], dostępny w internecie: <https://www.aspistrategist.org. au/australia-needs-a-clear-national-security-strategy>. 
Australian PM Scott Morrison warns global trade rules must be reshaped to account for China's rapid growth, „South China Morning Post” [online], 24 IX 2019, [dostęp: 17 X 2019], dostępny w internecie: <https:/www.scmp.com/news/china/article/3030046/ australian-pm-scott-morrison-says-china-must-step-climate-change-newly $>$.

Bitzinger R.A., China's military buildup: regional repercussions, [w:] China's power and Asian security, ed. M. Li, K. M. Kemburi, Routledge, London-New York 2015.

Canrong J., A changing Sino-American relationship in a changing world, [w:] Sino-American relations. Challenges ahead, ed. Y. Hao, Routledge, London-New York 2016.

China's national defense in the new era, The State Council Information Office of the People's Republic of China, Beijing, July 2019, dostępny w internecie [dostęp: 17 X 2019]: <http:// www.xinhuanet.com/english/download/whitepaperonnationaldefenseinnewera.doc $>$.

China's power and Asian security, ed. M. Li, K. M. Kemburi, Routledge, London-New York 2015.

Chinese foreign policy under Xi, ed. H.T. Boon, Routledge, London-New York 2017.

Collinson E., The Australian government on Xinjiang (October 2019 update), „Australia-China Relations Institute" [online], 15 X 2019 [dostęp: 10 II 2019], dostępny w internecie: $<$ https://www.australiachinarelations.org/content/australian-government-xinjiang-october2019-update>.

Conflict and cooperation in Sino-US relations. Change and continuity, causes and cures, ed. J.M.F. Blanchard, S. Shen, Routledge, London-New York 2015.

Czaputowicz J., Bezpieczeństwo międzynarodowe. Wspótczesne koncepcje, Wydawnictwo Naukowe PWN, Warszawa 2012.

Denmark A.M., US strategic rebalancing and the rise of China, [w:] New dynamics in US-China relations contending for the Asia-Pacific, ed. L. Mingjiang, K.M. Kemburi, Routledge, London-New York 2015.

Fang J. Kilbride J., Shelton T., Chinese-Australian relations have had a rollercoaster year in 2018, „ABC News” [online], 27 XII 2018 [dostęp: 18 II 2019], dostępny w internecie: <https:// www.abc.net.au/news/2018-12-27/chinese-australian-relations-have-had-a-rollercoasteryear/10638590>.

Full text of Chinese president Xi Jinping's address to Australia's Parliament, „,The Straits Times" [online], 19 XI 2014, [dostęp: 17 X 2019], dostępny w internecie: <https://www. straitstimes.com/asia/australianz/full-text-of-chinese-president-xi-jinpings-address-toaustralias-parliament>.

Goh E., Evaluating Southeast Asian responses to China's rise: the vital context of managing great power resurgence, [w:] China's power and Asian security, ed. M. Li, K. M. Kemburi, Routledge, London-New York 2015.

Hao Y., Zweig D., Introduction: Sino-US energy competition in resource rich states, [w:] Sino-US energy triangles. Resource diplomacy under hegemony, ed. D. Zweig, Y. Hao, Routledge, London-New York 2016.

Herberg M., US energy security strategy and China's energy diplomacy, [w:] Sino-US energy triangles. Resource diplomacy under hegemony, ed. D. Zweig, Y. Hao, Routledge, London-New York 2016.

Hodge A., ASEAN summit: Chinese premier Li Keqiang says Australia's relationship with Beijing is at a turning point, „The Australian” [online], 14 XI 2018, [dostęp: 17 X 2019], dostępny w internecie: $<$ https://www.theaustralian.com.au/nation/politics/asean-summit- 
chinese-premier-li-keqiang-says-australias-relationship-with-beijing-is-at-a-turning-point/ news-story/7b3fe77630438e9acd33ae2a8d213ce4>.

Hu R.W., Strategic trust deficit and its impact on the future of China-US relations, [w:] New dynamics in US-China relations contending for the Asia-Pacific, ed. L. Mingjiang, K. M. Kemburi, Routledge, London-New York 2015.

Kamiński R., Wybrane aspekty polityki zagranicznej Australii u progu XXI wieku, [w:] Wielka Brytania i Wspólnota u progu XXI wieku. Przeszłość - teraźniejszość - perspektywy, red. I. Penier, Wydawnictwo Uniwersytetu Łódzkiego, Łódź 2014.

Kmiecik P., Realizm strukturalny ofensywny, defensywny i zależny, „Nowa Strategia” [online], 26 XI 2016 [dostęp: 17 X 2019], dostępny w internecie: <http://www.nowastrategia.org.pl/realizm/>.

Lanteigne M., Chinese foreign policy. An introduction, 3 ed., Routledge, London-New York 2016.

Laurenceson N., Trade provides the ballast for relations with China, „Australian Institute of International Affairs" [online], 4 VII 2019 [dostęp: 5 II 2019], dostępny w internecie: <http://www.internationalaffairs.org.au/australianoutlook/trade-provides-the-ballastfor-relations-with-china/>.

Medcalf R., Canberra's Beijing balance: Australian perceptions of and responses to Chinese power, [w:] China's power and Asian security, ed. M. Li, K.M. Kemburi, Routledge, London-New York 2015.

Medcalf R., Grand stakes: Australia's future between China and India, [w:] Asia responds to its rising powers: China and India, ed. A.J. Tellis, T. Tanner, J. Keogh, National Bureau of Asian Research, Seattle 2011.

Mishra R., Australia-China strategic partnership, Institute for Defence Studies and Analyses, [New Delhi], 13 V 2013, dostępny w internecie [dostęp: 20 II 2019]: <https://www.files. ethz.ch/isn/164925/IB_Australia-China_RMishra130513.pdf $>$.

Molan J., Australia needs a clear national security strategy, „The Strategist” [online], $12 \mathrm{X}$ 2018 [dostęp: 18 II 2019], dostępny w internecie: <https://www.aspistrategist.org.au/ australia-needs-a-clear-national-security-strategy>.

New dynamics in US-China relations contending for the Asia-Pacific, ed. L. Mingjiang, K.M. Kemburi, Routledge, London-New York 2015.

Okraska T., Stosunki australijsko-chińskie. Historia, stan obecny, perspektywy, [w:] Australia w XX i XXI wieku. Polityka, historia i kultura, red. A. Kandzi-Poździał, J. Siekiera, Wydawnictwo Uniwersytetu Śląskiego, Katowice 2016.

Power J., US and Australia grow apart on China, behind the smiles and handshakes, „South China Morning Post" [online], 20 IX 2019 [dostęp: 17 X 2019], dostępny w internecie: $<$ https://www.scmp.com/week-asia/politics/article/3028141/us-and-australia-grow-apartchina-behind-smiles-and-handshakes>.

Rajagopalan R.P., India-China relations: a new turn under Xi Jinping?, [w:] Chinese foreign policy under Xi, ed. H.T. Boon, Routledge, London-New York 2017.

Report for selected countries and subjects, „International Monetary Fund” [online], April 2018, [dostęp: 5 II 2019], dostępny w internecie: $<$ https://www.imf.org/external/pubs/ft/ weo/2018/01/weodata/weorept.aspx?pr.x=61\&pr.y $=5 \&$ sy $=2016 \&$ ey $=2023 \&$ scsm $=1 \&$ ss$\mathrm{d}=1 \&$ sort $=$ country $\& \mathrm{ds}=. \& \mathrm{br}=1 \& \mathrm{c}=193 \& \mathrm{~s}=$ NGDPD,PPPGDP,NGDPDPC,PPPPC,LP\&grp $=0 \& \mathrm{a}=>$.

Ross R.S., Chinese security policy. Structure, power and politics, Routledge, London-New York 2009. 
Saunders P.C., China's rising power and the U.S. rebalance to Asia: implications for U.S.China relations, [w:] China's power and Asian security, ed. M. Li, K.M. Kemburi, Routledge, London-New York 2015.

Seng T.S., Engaging China and the United States: perils and prospects for ASEAN diplomacy in the age of rebalancing, [w:] New dynamics in US-China relations contending for the Asia-Pacific, ed. L. Mingjiang, K.M. Kemburi, Routledge, London-New York 2015. Sino-American relations. Challenges ahead, ed. Y. Hao, Routledge, London-New York 2016. Sino-US energy triangles. Resource diplomacy under hegemony, ed. D. Zweig, Y. Hao, Routledge, London-New York 2016.

Strong and secure. A strategy for Australia's national security, Australian Government Department of the Prime Minister and Cabinet, Canberra 2013, dostępny w internecie [dostęp: 10 II 2019]: <https://www.files.ethz.ch/isn/167267/Australia\%20A\%20Strategy\%20 for $\% 20$ National $\% 20$ Securit.pdf $>$.

Tai M., US-China relations in the twenty-first century. A question of trust, Routledge, LondonNew York 2015.

Tseng K.H.-Y., Rethinking South China Sea disputes. The untold dimensions and great expectations, Routledge, London-New York 2017.

Walt S.M., The origins of alliances, Cornell University Press, Ithaca-New York 1987.

Waltz K. N., Theory of international politics, Random House, New York 1979.

White H., How to defend Australia, La Trobe University Press, Melbourne 2019.

Wielka Brytania i Wspólnota u progu XXI wieku. Przeszłość - teraźniejszość - perspektywy, red. I. Penier, Wydawnictwo Uniwersytetu Łódzkiego, Łódź 2014.

Wyeth G., Why did Australia block Huawei, ZTE from $5 G$ roll out?, „The Diplomat” [online], 28 VIII 2018 [dostęp: 18 II 2019], dostępny w internecie: <https://thediplomat. com/2018/08/why-did-australia-block-huawei-zte-from-5g-roll-out/>.

Yu P.K.-h., Ocean governance, regimes, and the South China Sea issues. A one-dot theory interpretation, Springer, New York-Singapore 2015.

Zhao S., China and America: showdown in the Asia-Pacific?, [w:] Conflict and cooperation in Sino-US relations. Change and continuity, causes and cures, ed. J.M.F. Blanchard, S. Shen, Routledge, London-New York 2015. 